\title{
Baby Ghosts: Child Spirits and Contemporary Conceptions of Childhood in Thailand
}

\section{Megan Sinnott}

\begin{abstract}
The currently popular practice of propitiating, or 'adopting', child spirits in Thailand reveals an ambivalent attitude towards childhood. According to Buddhist scholars on childhood, Buddhist conceptions of children do not differentiate children in significant ways from adults in terms of their relative purity or innocence, as both children and adults possess countless lifetimes of karma; children are thus agentive beings, although not yet fully realised as adults. The child ghosts reflect the complex, competing conceptions of childhood, where they are both valuable resources to be deployed in the assistance of their families, and vulnerable beings in need of adult caretaking. Child ghosts are markers of both material and sentimental resources for their adoptive parents, or 'guardians'. This article explores representations of child ghosts in popular media, and investigates child ghost propitiation practices through interviews with child ghost guardians. In addition, an overview is provided of the various categories of child ghosts, including kumanthong, kuman-thep, kuman-phrai, luk-krok, and rak-yom.
\end{abstract}

KEYWORDS: kumanthong, child, spirit, ghost, Thailand

\section{INTRODUCTION}

$I^{\mathrm{N}}$

CONTEMPORARy ThaIland, the belief in and propitiation of baby/child spirits is experiencing a surge in popularity. Celebrities have written books on their baby ghost collection (Chakraphan Karnsompop and Chakraphong Karnsompop n.d.), websites are devoted to the topic ${ }^{1}$, popular ghost magazines regularly cover stories of the subject (e.g. Prasopkarn Khon Hen Phi [The Experiences of People Seeing Ghosts]; Rueang Phi [About Ghosts]; and Phi 48 [48 Ghosts]), and spirit mediums and temples, as well as eBay, do a brisk business in supplying the public with figurines housing helpful child spirits. Sensational stories about foetal/infant bodies put to nefarious magical purposes occur regularly in the press. Perhaps it is not too strong to say that, amongst some sectors of the population, there is a cultural obsession with the power of the child, specifically the supernatural

Megan Sinnott, Georgia State University; megansinnott@gsu.edu

${ }^{1}$ For example, see: http://www.kumarnthong.com/; http://www.kumanthongsiam.com/; http://xn12cmlcybcfe2dzalcg7d.blogspot.com/; and http://kumarntalk.net/; all accessed on 25 September 2011. 
power of the child's ghost. Relationships with these spectral children, made possible through death, allow access to the child's power. The child's spirit is bound to its propitiator giving him/her access to the supernatural power of the child spirit. These child spirits, ritually bound to their 'parental' guardians reflect complex and competing notions of childhood circulating within the Thai context.

Childhood is an "empty screen" onto which adults may project their fears and fantasies (Marshall 2011: 297), and is thus socially constructed in ways that reflect larger cultural and historical contexts. Janet Jakobsen and Ann Pellegrini claim that children "serve as placeholders for larger cultural anxieties about changes in national identity, gender relations, and family structure" (2003: 90-91). This article seeks to explore one set of images, discourses and practices that reflect constructions of childhood in contemporary Thailand - the popular practice of propitiating, or 'adopting' [ rap liang], foetal/infant/child ghosts, which have collectively come to be called 'kumanthong'. Kumanthong were traditionally a material thing; an amulet or foetal corpse that was magically endowed with the spirit of a foetus. Now, however, the term has come to encompass both these material objects and the often disembodied spirits of foetuses, babies and small children. While the belief in kumanthong, as an amulet or magically endowed foetal corpse, dates from at least the seventeenth century (Baker and Phongpaichit 2010a), the current practice of propitiating child spirits reflects contemporary attitudes in which child spirits are framed as both resource and companions for adults; they serve both material and emotional needs.

Child spirits [winyan dek] collectively includes foetuses, infants, and small children who are made available to adults through the child's death and subsequent transformation into a spectral presence. For example, both 'foetus' and 'infant' may be generally referred to as tharok, or distinguished as tharok (infant) and tharok nay khan (infant in utero). In fact, the age of a child spirit is almost never specified and even foetal ghosts are perceived as children in their interactions with adults. The foetus, infant and small child are collapsed into one category of agentive beings; they have personalities, individual will, and the power to enter or leave the caretaking of their adoptive family. The underlying premise that extends across all the varied forms of child spirit propitiation discussed here is the belief that child ghosts are controllable yet ultimately unpredictable sources of supernatural power that can aid in the propitiator's security, prosperity, and need for companionship.

Devotees referred to the practice of propitiating these spirits as raising a child. For example, they would typically refer to themselves as 'mother' or 'father' and call their spirit 'son/daughter' [luk]. Devotees describe their relationship with the spirits as one of caretaking and mutual responsibility, and I refer to them as 'guardians', 'devotees' or 'propitiators' of the child spirits to reflect their roles as both parents and propitiators of spirits.

This research is based on interviews with twelve individuals who propitiate child spirits, review of websites, popular magazines and television shows, 
observation at public shrines, and more general participant/observation in which I discussed kumanthong and child spirit propitiation more generally with dozens of individuals. Research was conducted throughout Thailand but with an emphasis on Bangkok from 2009 to 2013. Interviewees were selected through personal connections with individuals who practice child spirit propitiation. Pseudonyms are used to refer to these individuals in order to maintain privacy.

\section{Cultural Construction of Childhood}

\section{Buddhism and Thai Conceptions of Childhood}

According to Rita Gross, Buddhism is not particularly child-focused (1996). According to Gross (1996: 82), "In its classic forms, whether doctrinally or institutionally, Buddhism does not especially focus on children or on the family. It is not a child-centered or a family-centered religion." The reproduction of children, families and kin-lines are not a desired goal of Buddhism, which teaches the values of renunciation and detachment. Indeed, the stories of the future Buddha's abandonment of his own children, and other stories of monastics renouncing their children, tend to reaffirm the sense that Buddhism has little concern for children (Sasson 2013: 1-4). Vanessa Sasson argues, however, that these stories of renunciation are precisely what gives the stories their vibrancy and lend them impact. Likewise, as Gross explains, Buddhism is not antifamily or anti-children, but rather focuses on the mindset that accompanies the activities of family life or raising children. Of course, Thai-Buddhism, as it is practiced, is enmeshed with concerns with fertility and acquiring wealth (see McDaniel 2011a). Buddhism, through monastery schools, educates children (mostly males in Thailand, but also, more rarely girls [Falk 2007; 2013]) and within Thailand a booming business in child-focused texts that explicate Buddhism has developed (McDaniel 2013). However, these Buddhist doctrines, stories and principles infuse the understandings of children and, I argue, the belief in child spirits in that the child spirit (even a foetal ghost) is understood as an agentive being capable of taking care of his/her guardians and their family.

Gross states that Buddhism lacks the "cult of the divine child" (1996: 84) and does not distinguish the child's karmic processes from the adult's. Gross explains, "It should come as no surprise then, that the state of childhood itself is not regarded as a special state" and "Children are neither especially endowed with innocence and goodness beyond what adults possess, nor are children in an unredeemed or depraved state of nature different in quality from that of adults who have been initiated or processed in some way" (1996: 85). Karma (cause and effect) is central for understanding the child within Buddhist context, because, as Gross highlights, the child is no "blank slate" (1996: 85) but comes into this world having already accumulated countless previous lifetimes, and, like the adult, is moving through the karmic consequence of past mental states and 
actions. The concept of children as beings that are products of an unknowably long stream of past lives, past deeds and misdeeds, and subject to laws of karma sheds light on understandings of child spirits. They are not merely spectral traces of young and unformed beings, but rather are beings that are momentarily found in the interstices of the not yet reborn. Their eventual rebirth, like all births, will be the result of their accumulated past actions, or karma. Their rebirth, thus, depends also on their deeds, or misdeeds, they commit as they are spectral presences.

Childrearing in Buddhist traditions, and specifically within the Thai context, is seen as a reciprocal relationship. Yoshiharu Nakagawa (2006: 35), discussing the relationship of novices and their relationship to monks or nuns, claims, "In Buddhism a child is always seen in relationship to an adult who is taking care of child, just a relationship between mother and child is grasped as a unit of being." This notion of reciprocity is central to Thai notions of the reciprocal ties that unite parents and children. Simon Baker has identified the concept of 'bunkhun' - the repayment of moral debt and gratitude - as essential to understanding the relationship between children and parents. In gratitude for their birth, a child has an obligation to repay their parents (Baker 2007: 23). This repayment of bunkhun may take the form of being respectful and helpful around the house, ordaining as a monk (for males), and sending remittances from paid labour back home to parents (particularly true for females). These ties of bunkhun also unite the child spirit and his/her guardians. The child repays his or her guardian for offerings and general caretaking by the type of caretaking that may be done by powerful spiritual entities, such as guarding the home and ensuring good fortune.

\section{Transnational Shifts in the Conception of Childhood}

Conceptions of childhood in Thailand are also influenced by larger transnational discourses of the child, stemming from shifting conceptions of the child as an instrumental value versus an emotional value. The literature on cultural constructions of childhood is vast and primarily focused on western contexts, for example Ariès (1962); Heywood (2001); James and Prout (2007); Lancy (2008); Lesko and Talburt (2011); Marshall (2011); Shepler (2005); and Zhao (2010). Scholars of childhood have argued that in western contexts the value of children has shifted from an instrumental value to an expressive value (Scheper-Hughes [1989] cited in Boyden 1997: 192; Zelizer 1994). Jo Boyden describes the sentimental approach to childhood in this contemporary model in which the economic value of children is replaced by their psychological value to the parents. Boyden locates this shift in the processes of capitalist expansion and development in which the child's role in the household economy was diminished (see also Zelizer 1994). Instead, the child (and his/her caretakers) became the site of intensive development and control in order to prepare him/her for future involvement in capitalist production. Thus, perhaps counter-intuitively, the sentimentalised 
approach to childhood is thoroughly interwined in the commodification of the child and his/her labour potential within a neoliberal, capitalistic, world order. This sentimental versus instrumental value of children has become internationalised through instruments such as discourses of human/child rights and child welfare campaigns (Boyden 1997). Viviana Zelizer (1994: 179) described the way in which these two models co-existed in some cases as this shift in the valuation of children occurred: "But in nineteenth-century foster homes, the sentimental value of a child did not preclude the possibility of profitably employing that same child. Such an acceptable combination of children's economic and sentimental value was declared an illegitimate contradiction by child welfare workers." In this internationalised model the child is configured as both innocent and vulnerable, but also as potentially dangerous and socially disruptive.

Commodification of children and their labour is not in itself a new phenomenon, and in fact characterises many pre-capitalist social systems. David Lancy describes 'commodification' of children as a widespread aspect of childhood throughout much of history:

"I use admittedly extreme examples to make the point that for much of human history, children were, and still are in most of the world, treated as a commodity. Children enhance their parents' inclusive fitness..., they assist with the care of younger siblings, and they do farm work. They may be sold into slavery, sent to urban areas to fend for themselves in the streets, or their wages incorporated into the family's budget." (Lancy 2008: 12)

In this reading, commodification of children, or, I argue, their spectral representation, is not a unique aspect of modern capitalist society, although the incorporation of these representations of childhood into the capitalist marketplace, through online websites offering figurines for sale, etc., may be seen as such. The value of children, however, is normatively framed in hegemonic terms as one of sentimental value; the child's parents are to enter into parenthood with the expectation of emotional fulfilment through the process of childrearing.

The beliefs in and practices concerning the adoption of child ghosts in Thailand reflect both of the instrumental and sentimental constructions of childhood. On one hand, they are instrumental aids in providing labour to the household. They protect the home from burglars and aid in the general pursuit of household prosperity. On the other hand, they are important providers of affection and companionship. Some propitiators described daily interactions and consultations with their adoptive child ghost. They reflect the multiple models of childhood that exist in contemporary Thailand.

This dual approach to childhood is mirrored in the dual orientation towards spirit propitiation present in contemporary Thai spiritual practices. In one model the physical object in which the spirit resides is valued for its aesthetic properties 
(including its age and provenance, especially the magical expertise of its creators). Here the object is absorbed within an existing amulet market and has become the site of increasing commodification of the child ghost in a capitalist market system. In the second model, the spirit itself - its personality - is valued and little emphasis is placed on its physical housing. Here the child ghost reflects the turn to conceptions of sentimentalised childhoods, yet even within this model the child ghost's ability to aid in the general prosperity of the propitiator was consistently emphasised.

\section{Material Resources and Sentimental Companions}

The child spirits are ideally voluntary companions and as such their relationship to the living is based on mutual needs between the living caretakers and the child spirit. The spirits are believed to be waiting rebirth according to Buddhist conceptions of karma and reincarnation. These spirits build karmic merit by using their supernatural powers to assist the living in their pursuits of wealth, security and companionship. In return, the propitiators provide for the child through offerings of toys and food, and in some cases discussed here, invitations to inclusion into family activities. A relationship of exchange is formed which, according to propitiators, can be ended by either party (a child spirit may leave and a propitiator may return the spirit to a temple or spirit medium). Therefore, the practice of child spirit propitiation may be best described as adopting child spirits within a contractual arrangement.

The term kumanthong is somewhat slippery in that it can simply mean child spirit in general or more specifically the preserved body of a foetus/infant or a statue that is believed to hold a child spirit. In other words, a kumanthong may be perceived as a disembodied spirit with whom one may communicate, or it can be an object (a preserved corpse, statue, or amulet) associated with a more impersonal, less anthropomorphic supernatural power. For example, a child spirit may communicate with people in dreams, or be seen or heard in daily life. They may also be understood to be housed in a statue or in their own corpse and as such these items may be commodified according to their age, origin, aesthetic qualities, and perceived supernatural power.

These two understandings of kumanthong - one that sees them as more impersonal material objects imbued with magical powers, and the other that figures them as more personal, anthropomorphic spirits - reflect different attitudes towards the importance of magical expertise in the creation of kumanthong. The perceived need for magical intervention in the creation of kumanthong varies according to individual propitiators, with some highly valuing the magical expertise of some monks and laypeople who are wellknown for their power to invest figurines with kumanthong spirits/power. The necessity of a magical expert to invest a sacred figurine with a child spirit is at times avoided altogether in contemporary practices, and the spirit is seen as voluntarily residing with a propitiator, sometimes with no vessel to house it all - it resides with his/her guardian as a pure spectral presence. However, with 
all contemporary kumanthong practices, propitiators insist on the voluntary participation by the child spirit in their own practices, and distinguish these practices from the evil doings of those who practice 'black magic' [mon dam] to control and capture child spirits to do their bidding.

These two, at times overlapping, conceptions of kumanthong are also reflected in the two models of childhood discussed above; kumanthong are both resources to be used for material gain (security and prosperity), and vulnerable children in need of tenderness and caretaking. These two themes interweave, and at times clash, as will be shown below. These themes pull on larger discourses of childhood in circulation in contemporary Thailand. For example, state discourses, which regulate children's education, criminalisation, and social services, depend on the concept of childhood innocence in order to justify management and control of children's decisions and lives. Transnational narratives of childhood's innocence and inherent need of adult protection and guidance are of course evident in contemporary Thai discourse. For example, according the Children's Protection Act of 2003 [phrarachabanyat khum khrong dek 2546], a child is defined as a person under the age of eighteen who is not yet married (Waraporn Chamsanit 2008: 16). ${ }^{2}$ As Waraporn (2008) notes, according to this legal statute, childhood is defined in opposition to state-sanctioned sexual knowledge and is therefore framed as inhabiting a state of asexual innocence.

In the following section, definitions and descriptions of types of child spirits will be introduced, including the literary background of kumanthong in order to explore how the kumanthong shifted from being purely a resource to be exploited by a magical practitioner/parent to being a child in need of caretaking. We shall then turn to public kumanthong shrines and examine how they reflect this shifting valuation. In concluding we explore the kumanthong as both a collectable and a companion.

\section{Definitions}

Child spirits are called by the generic term kumanthong, which can be literally translated as 'golden [thong] boy [kuman]'. The less popular female child ghost is called kumari, or sometimes kuman-kaew. Two devotees spoke of spirits as having both sexes and referred to these spirits as kathoey. ${ }^{3}$ However, the term kumanthong typically is used generically to refer to both male and female child spirits. Devotees told that in general boy kumanthong were preferred

\footnotetext{
${ }^{2}$ Thai authors are listed according to their first (given) name rather than their family name in compliance with convention.

${ }^{3}$ Kathoey refers to those people who are mixed gendered or intersex. While in this case it refers to a body with the genitals of both sexes, it more commonly refers to a psychological transgendering in which a person with a male body is considered to have a woman's 'soul' or 'heart' [citcay].
} 
because they were understood to be more powerful than female spirits. Yet, it is precisely the ability to control the child spirits and their relatively unthreatening status as children that makes them sought after.

I asked devotees if power was what was needed, why not invite an adult spirit? Devotees responded with shudders of horror and said that adult spirits were terrifying and not to be dabbled with. In fact, ghost stories, including films, often revolve around would-be magicians' attempts to control an adult spirit, with horrifying results. The appeal of kumanthong, therefore, is in the ambiguous power of the child, who often has male power but in a child-like and controllable form. Conceptions of childhood innocence and purity are coupled with supernatural power that can exceed the power of a living adult.

However, one particularly striking feature of the kumanthong adopted by the devotees is that they are not necessarily children anymore. In fact, the age of the spirits may vary widely, from a foetal stage up until mid-life. The exact age of the spirits is not particularly significant, however, as many devotees simply guessed at the age when prompted. The spirits are not necessarily trapped within the age that they died, and are often understood to age until they reach the age that they were destined to die, at which point they are ready for rebirth. For example, one devotee, $\mathrm{Jim}^{4}$, a professional woman in her early thirties, explained that kumanthong grow and age. One spirit is actually not a child at all, but, she explained, a twenty or thirty year-old. She raised him since he was around ten years old in a kind of parallel development cycle.

Child spirits are often linked to particular adult spirits who in a sense parent the child spirit. The best example of this is the linkage of foetal/infant spirits with their mother if the mother dies in childbirth. In fact, the most powerful and threatening spirits are those of women who have died in childbirth or while pregnant, whose spiritual power is in a sense doubled by the presence of the foetal/ infant spirit within them. These spirits usually have a grudge against the living; a wrong has been done to them that fuels a supernatural rage. This terrifying spiritual form is the subject of many popular ghost legends and films, including the iconic Nang Nak legend, as well as more contemporary novels and television serials, such as Sap-phu-sa. ${ }^{5}$ However, the image of deceased pregnant women as a powerful and threatening spiritual entity finds a masculine counterpart in the iconic origin story of kumanthong found in the epic story Khun Chang Khun Phaen. This story is widely known in Thailand, having been made into a feature film, and is almost always referenced in public discussions of child spirits or kumanthong. It is important to briefly review this story as it clearly displays the notion of kumanthong, or child spirits more generally, as resources to be exploited by adults.

\footnotetext{
${ }^{4}$ All names of interviewees are listed as pseudonyms, listed as typical Thai nicknames.

${ }^{5} \mathrm{Sap}$-phu-sa is a television program based on the novel of the same name written by Phongsakorn in 2007, published by Pheuan-Dee Publishers.
} 
The story Khun Chang Khun Phaen was originally orally transmitted and transcribed in various versions and forms over the centuries, starting possibly in the seventeenth century (Baker and Phongpaichit 2010a). It is essentially a story of a love triangle, with the emblematic masculine figure Khun Paen as the tragic hero. He is a masculine icon, whose mastery of magic allows him unparalleled success in both seducing women and in battlefield conquests.

The character Khun Paen is inextricably linked to myths surrounding kumanthong as he very vividly creates one to aid him in battle. In the most popular version of the story, he cuts the male foetus from his bandit lover, Buakhli, whom he has just murdered in retribution for her plotting against his life:

"He plunged the knife into her chest, piercing right through. She writhed and died. Red blood spurted out and spread all around like the killing of a buffalo. He cut her belly wide open, and severed the umbilical cord. Examining the baby, he was happy to find it was the male he wanted." (Baker and Phongpaichit 2010b: 1193)

He then transforms the foetus into the magical entity/amulet kumanthong by roasting it over a fire according to ritual:

"He meditated to focus his mind, and sat grilling the Goldchild [kumanthong], heating the whole body, turning it over front and back so the fat dripped and sizzled. Just as the dawn brightened and a golden sun rose, it was dry and crisp as he wanted." (Baker and Phongpaichit 2010b: 1194$)^{6}$

While contemporary audiences may be horrified by the grisly murder and even grislier procedure Khun Phaen engages in to make a kumanthong, this act does not condemn Khun Phaen, nor does it create a vengeful spirit. Vengeful aborted spirits are a particular variant of child ghost beliefs and it has been argued that these beliefs are largely products of international circulation of Japanese beliefs and practices (see Hardacre 1997 and Moskowitz 2001). Indeed, he is celebrated at Wat Khae temple in Suphanburi Province that claims to be the legendary temple in which Khun Phaen learned his magical arts. Wat Khae has marketed Khun Phaen's image and celebrity as a legendary character; he is presented in the temple narrative as a historical figure worthy of adulation and there are shrines at the temple for all the major characters of the story including Khun Phaen himself. The reason for this positive reading of Khun Phaen overall is that his act may be best understood as a re-appropriation of female generative powers; rather than an act of killing, his was an act of creation in the transformation of an

${ }^{6}$ This version of the story was a later addition added by Khru Jaeng, reflecting a popular telling of the story, in the Fourth Reign (AD 1851-1868) (Baker and Phongpaichit, 2010b: 1174); Professor Lom Pengkaeo, personal communication 5 July 2011). 
ordinary foetus into a magical life force for the explicit purpose of aiding Khun Phaen in his adventures.

This legend must have reflected familiar practices during the time of its writing (Professor Lom Pengkaeo pers. comm. 5 July 2011) ${ }^{7}$ and thus the practice of producing and raising kumanthong must be at least several centuries old. Therefore, the term kumanthong dates from at least the seventeenth century, although the specific history of the term and the practice of making and raising kumanthong have not been studied to my knowledge.

Traditionally, kumanthong were understood to be made by men, specifically experts in magic and ghost manipulation, or mor-phi, in the fashion that Khun Phaen made his kumanthong; usually a male foetus is grilled and dried out, and then covered in gold leaf [thong], similar to practices of covering all sacred objects in gold leaf, hence the name kumanthong or 'boy of gold' (Professor Lom Pengkaeo pers. comm. 5 July 2011). Magical incantations capture the foetal spirit and put it in service to the mor- phi, or magical expert. In the original story Khun Chang Khun Phaen the act of creating a kumanthong from a foetus through magical powers was not framed in terms of moral judgment. However, in contemporary public discourse a crucial distinction is made between magically-restrained kumanthong versus volunteer kumanthong produced and housed in Buddhist temples, or 'collected' by individuals.

The kumanthong that Khun Phaen creates shares the primary characteristic of the helpful kumanthong that contemporary guardians value; their other worldly power can be channelled and directed towards service to their guardian. However, the ways in which kumanthong are categorised and defined have shifted to minimise the associations of the spirit with ghosts (the spectral presence of the dead), that is phi, and to place kumanthong in more lofty, Buddhist-influenced categories of heavenly creatures. Contemporary devotees divide the kumanthong spirits into the categories kuman-thep, kuman-phi, kuman-phrai, and other forms of child spirits including luk krok and rak-yom, to be described below. All of these categories of child spirits are typically subsumed under the general category of 'kumanthong'. However, one devotee insisted his spiritual child companions were not kumanthong but were thep, implying that kumanthong referenced phi, or ghosts, rather than the loftier thep. In this case, a sharp distinction was made between kumanthong and kuman-thep, whereas they are typically merged. These different categories roughly conform to a Buddhist hierarchy of life forms, which includes spiritual beings both lower and higher than humans. In fact, many of the aspects of the kumanthong are linked to Buddhist concepts and practices. For example, on

\footnotetext{
${ }^{7}$ Professor Lom Pengkaeo is a retired professor at Phetchaburi Rajabhat Institute (now Phetchaburi Rajabhat University). He is a widely acclaimed expert in Thai language and literature. For further biographical information and list of credentials, see: http://research.pbru.ac.th/web/attachments/ 209_farther1.pdf, accessed 6 December 2012, and http://www.web.msu.ac.th/halloffame/SDetail. php?hid=1290, accessed 6 December 2012.
} 
Wan Phra, a day devoted to Buddhist ritual based on a lunar calendar, special offerings are made. The statue that embodies the kumanthong itself may be arranged on a series of shelves housing various sacred beings, with the Buddha image raised higher than the others.

With the important exception of kuman-thep, the kumanthong are typically considered to be the spirits of deceased children and to be wandering ghosts, or phi re-ron. These spirits may come to reside in amulets or small statues, or even an ordinary toy figurine will do. The use of statues is probably a modern invention to replace the preserved foetal body of traditional kumanthong beliefs (Professor Lom Pengkaeo pers. comm. 5 July 2011). As mentioned above, some kumanthong have no specific statue or residing places. Many devotees obtain their kumanthong from temples or spirit mediums who specialise in the investment of power into objects [pluk-sek]. Some guardians describe their relationship with a kumanthong to be arranged directly with a child spirit who comes to them in a dream.

Kuman-thep, or deity-kuman are differentiated from kuman-phrai, which refers to the ghosts of foetus or infants, ${ }^{8}$ and is a subset of the larger category of ghost, or phi. According to one twenty-one year old collector of kumanthong, Kay, kuman-phrai are specifically those foetuses/infants who died from violent deaths or died from abortion. According to Kay, kuman-phrai have the most power [hian or ithalit], even more so than the lofty kuman-thep. Kuman-phrai are potentially dangerous if they are not cared for properly. Kay also introduced the category of kuman kueng thep/kueng phrai, or kumanthong in between thep and phrai status. Kay explained that these are ghosts, phi, are basically well-intentioned and striving to make merit for their propitiators.

The distinction between lofty kuman-thep and lowly kuman-phrai or phi is probably a modern adaptation, and previous categorisation would include all the kumanthong forms under the category 'phi' or ghost, which did not have the negative connotation as it does now (Professor Lom Pengkaeo pers. comm. 5 July 2011). Phi are traditionally forces of nature, ancestral spirits, and other non-worldly beings, and not necessarily the monstrous figures that they have come to be in contemporary horror genre of film and fiction.

For contemporary propitiators, kuman-thep are generally described as higher spiritual beings, that is they are child thep in Buddhist cosmology. On the other hand, kuman-phrai are a form of phi, that is the ghosts of dead foetuses, babies, or children. One devotee said that kuman-thep are "invited from the heavens" to accompany and live with the devotee, whereas kuman-phrai/phi are the rather

\footnotetext{
${ }^{8}$ According to Professor Lom Pengkaeo, phrai originally meant ghosts of those who died in water or those spirits who reside in water (pers. comm. 5 July 2011). According to an 1854 Thai-English dictionary, phi-phrai are combined into one word meaning "Demons which the sorcerers entertain in the house," and phrai alone means "Demon kept in the house; abortive child that sorcerers keep in their house like a demon (Dictionarium Linguae Thai, Paris 1854 [2397]). In this definition the meaning of phrai overlaps with the term kumanthong, which is not in this dictionary.
} 
pitiful wandering spirits of the deceased who either find their way to their guardian or are sought after by their guardian. Different offerings are made to each category of kumanthong, and different rituals bind them to their guardians.

All kumanthong are propitiated and given offerings, but as higher spiritual beings, thep are not considered to be involved in a direct exchange relationship with their guardians in the same way that kuman-phrai or phi are. When the spirits are bound to their devotees, certain contractual arrangements are made, according to one devotee. For phi, this takes the more direct form of kae-bon, or a plea for assistance for some particular project in exchange for a specific offering. All devotees agreed that thep are not propitiated in a direct fashion, and the thep may provide more general aid, such as watching over the household and providing good luck. Propitiators may ask for general blessings in their projects, but not a direct exchange of specific assistance for specific gifts. Iat, a male devotee in his 30s, explained that offerings to kuman-thep are usually plain water, or other beverages only, in contrast to the elaborate food and toys offered to kuman-phi. Iat claims that thep, in contrast to $p h i$, as a higher spiritual being cannot be forced into service and are by definition spirits who aid their guardians out of free will.

Referring to a child spirit as a thep (heavenly being) rather than a phi or a phrai (ghost) has the effect of reducing the stigma of death from the spirit. In a sense it cleanses the spirit of macabre associations with corpses and death, and relegates the spirit to a lofty heavenly plane of deities, whom, while are also subject to death, rebirth and the laws of karma, have lifespans so immense that they are, from human perspectives, immortal. The division between phi and thep produces a bourgeois cleansing of kumanthong of negative associations with death (they are now thep) and corpses (they may now be commodified figurines).

There is considerable difference of opinion among devotees about the definition and characteristics of all of these spiritual beings, but this is particularly true of rak-yom. Contemporary propitiators with whom I spoke claim that rakyom is a spirit of a deceased child materialised in an amulet composed of two pieces of wood in oil in a small jar. ${ }^{9}$ This contemporary understanding that rak-yom, like other kumanthong, are spirits [winyan] of children that are lower than thep contrasts with more traditional understandings of rak-yom. According to Professor Lom Pengkaeo (pers. comm. 5 July 2011), the wooden figure in the amulet is in the form of a child, but the actual spirit that inhabited

\footnotetext{
${ }^{9}$ The wood is from the tree ton-rak (Calotropis gigantean, or crown flower, Melanorrhoea) and the tree ton-ma-yom (star gooseberry, Phyllanthus distichus). This is a play on words, where the word rak is part of the name of a tree yet also means love, and so the amulet symbolises the power of love. The word yom, as in the may-yom tree, also is a root of the word niyom, to admire. Therefore, the amulet has the power to make people love and adore the owner. As a side note, I found a website for ordering Thai amulets that offered a free rak-yom amulet with orders (http://thailand-amulets.net/? tag=rak-yom accessed 5 December 5 2012). See also: http://www.oldamulet.com/1009-5-qty-thaiamulet-kmt-rak-yom-twin-baby-ghost-strong-charming-lp-nen-2554 accessed 5 December 52012.
} 
the amulet was believed to be a child or any other spirit, and as such was not necessarily a form of kumanthong.

According to one devotee, Kaew, a 20 year old college student, who understood rak-yom as child spirits, held that they are also more powerful [raeng $k w a$ ] than ordinary kumanthong. Kaew defined rak-yom as the product of black magic in which a child spirit is enticed and captured through spells within an amulet. Jim claimed that they are forced to serve their guardian and they have a tendency to seek retaliation if they are not propitiated correctly, making them a dangerous type of spirit. Jim also claimed that they are typically used for malevolent purposes, such as seeking revenge against others. Iat, however, claimed that these spirits are not usually forced, and like all ghosts, or phi, they may be forced through black magic to aid their propitiators, or may come of their free will. The voluntary nature of the spirit in aiding their propitiator was of central importance in defining this amulet/spirit.

Luk-krok seem to bear the most similarity to the foetal body that comprise the traditional kumanthong. According to Kaew, luk-krok are amulets that are made from a perfectly formed, preserved foetus. No spells are necessary in the creation of luk krok, according to some informants, while others insist that luk krok are the product of black magic. Kaew claimed that the emotional tie of motherhood is enough to bind the child to its devotee, who is usually the mother. Likewise, Iat described them as typically possessed by the mothers of the foetuses who keep them as companions who assist their mothers in daily life activities. ${ }^{10}$

As can be seen from this discussion, there is considerable variety in interpretations of these terms. Ghost baby/child, or phi dek, is often used interchangeably with kumanthong, with the former more specifically referring to the spirit of the child and the later incorporating the actual objects that are believed to house these spirits.

\section{Childhood and Volunteer Kumanthong}

While Khun Phaen is still revered as a cultural icon for his masculine powers, the practice of making kumanthong from foetuses currently is reviled as a form of child exploitation and cruelty. In fact, stories of individuals arrested for attempts to make or sell these kumanthong periodically appear in the press. For example, on 18 May 2012, the news story broke that the remains of six foetal remains covered in gold leaf were found in the possession of a British man of Taiwanese

\footnotetext{
${ }^{10}$ In a recent Thai language dictionary (2004), kumanthong is translated as the ghost $[p h i]$ of a child that is made with magic and is raised to be used for its benefits [phi dek sueng tham khuen maa doy withi sayasat aw ma liang wai chai ngarn]. Luk krok is translated as the child of a person or animal that died while in the womb and has not decayed [luk khon rue sat thi tay tang tae yu nay thong lae mai nao puey] (Matichon Dictionary of the Thai Language. Bangkok: Matichon).
} 
descent who had planned to smuggle them out of Thailand and back to Taiwan to sell them. ${ }^{11}$ The story was sensational and gruesome enough to be picked up by international press, and was reported in the United States on the CNN website. ${ }^{12}$ However, in this news story the kumanthong were presented as hapless victims and children in need of adult compassion.

A further example of this framing of kumanthong as helpless children is found in the online reporting of Rong-Ot Sarakham who posted a story about the case on Youtube with a short printed narrative entitled "Rong-Ot Pities Kumanthong." 13 The narrative read in part "[I] just really feel sorry for the little kumanthong. Instead of being reborn, they were sold by an evil hearted person to be used in black magic." Rong-Ot used the word nong before kumanthong, which is a term used to address a younger sibling, thereby expressing an affectionate connection that humanises the kumanthong as part of a family.

This theme of kumanthong as helpless children in need of adult caretaking was repeated in an interview Rong-Ot conducted with one of the police officers, Police Lieutenant Colonel [phan tam-ruat tho] Jitima Thongchai, working at the police station that was handling the case, the video of which was posted on Youtube. Situating the child spirits as suffering and in need of compassion, this officer told the story of the child spirits communicating with her late at night as she worked. The remains of the infants/foetuses (the distinction was never made and is generally not made when talking about child spirits) were being held at the station as the case was investigated. In the interview, the officer said she was working until about nine in the evening when she heard the sound of children crying. She asked her workmate if he was doing something on his computer to make the sound, and he replied that he was not. She told him she heard the sound of children crying, and her workmate said he heard it too. She said she had never raised kumanthong so she asked her workmate what to do, and he suggested they buy snacks and beverages for the kumanthong, and she did so. The workmate had a break and went to smoke outside the building and he heard whispering in his ear, "big sister is really good-hearted", referring to the police officer who had bought them snacks.

This narrative is significant for several reasons. First, a high ranking police officer was publically interviewed in which she related hearing kumanthong crying. She responded by making sensible offerings (snacks) to comfort the

\footnotetext{
${ }^{11}$ Bangkok Post. 18 May 2012; http:www.bangkokpost.com/print/294023 (accessed on 21 May 2012).

${ }^{12} \mathrm{http}: / /$ www.cnn.com/2012/05/18/world/asia/thailand-fetuses-black-magic/index.html (accessed on 12 October 2012).

${ }^{13} \mathrm{http}: / /$ www.youtube.com/watch?v=OkaejdcX3x4\&feature=youtube_gdata_player (accessed on 12 October 2012). Rong-Ot Sarakham is a pseudonym or a screen name. The reporter's real name is Nopphadol Srithaweekas. He works as a reporter at Kom Chad Luek Newspaper and Nation Multimedia Group Public Company Limited.
} 
child ghosts. This incident, and her openness in relating it, demonstrates the normativity in experiencing ghosts, in this case child ghosts, and the practice of propitiating them through appropriate offerings. Second, this narrative also demonstrates a widespread theme in which child spirits are framed as innocent, vulnerable, and in need of adult protection and caretaking. The 'evil-hearted person' who was planning on trafficking the kumanthong for the purposes of personal gain is contrasted to the 'good-hearted' police officer who felt sorry for them and offered them treats. This incident reveals two modalities in approaching kumanthong; on the one hand they are a resource for adult devotees, and on the other they are needy children requiring adult caretaking. These two modalities are in sharp contrast in this incident, yet they are more harmoniously merged in public, communal kumanthong shrines in which kumanthong are presented either in the form of preserved foetal/infant remains or as spirits housed in kumanthong statues.

\section{Shrines as Community Resource}

Some shrines for particular kumanthong are found at Buddhist temples; in this setting these shrines are consecrated as appropriate spaces for the 'housing' of kumanthong, who are then available for the general public to accept offerings and provide assistance that they as supernatural beings can provide. Kumanthong shrines sometimes have the actual preserved body of a foetus or baby, while others mark the presence of a kumanthong spirit with a statue or figurine. Other shrines, while not primarily devoted to the worship of kumanthong, include kumanthong spirits as assistants to the more powerful, adult spirit of the shrine.

The infant/foetal corpse is incorporated into a religiosity that revolves around prosperity and protection - the main goals that propitiators hope to achieve in the interactions with kumanthong. Justin McDaniel (2011: 26) aptly characterises Thai religious concerns with "the local values of security, heritage, graciousness, and abundance." In this setting, the kumanthong are not created or maintained for an individual's benefit, and are thus not understood as being victimised or exploited. A reciprocal relationship is formed between propitiators and the kumanthong for their mutual benefit. The kumanthongs' voluntary presence is central to this benign reading of their interactions with adults.

One example of a well-known kumanthong shrine that houses a preserved body is at Wat Pradu in Bangkok. This shrine houses the preserved body of conjoined twins who died in birth. The shrine, located just outside of the main temple, consists of a jar in which the body is on display surrounded by offerings. The conjoined twins have two heads joined to one body. According to a monk watching over the temple, the body of the babies was brought to the temple for burial rights by the father over fifty years ago (approximately the 1960s). 
The abbot asked to keep the baby and to make a shrine for its propitiation. The babies, as conjoined twins, are considered to have particularly strong power, in that they are a doubling. Offerings of toys and snacks to the twins are made always in double - two of each toy, snack, etc. The monk at the shrine claimed that the body had grown over the years, implying that it embodied a life force; consequently the casing for the body had to be changed four times to house the larger body. ${ }^{14}$ People came to the shrine (mostly women while I was there in July 2010), made offerings to the spirits and made requests for assistance, such as help in choosing lottery numbers.

After the sensational case discussed above in which the remains of six foetuses were found bound for export to be used as kumanthong, there is a level of ambivalence towards kumanthong shrines in which the foetal/infant remains are preserved. For example, a popular kumanthong shrine that houses a preserved body is found at Wat Mahabut, Bangkok, famous for its shrine to Nang Nak (the ghost of the woman who died in childbirth mentioned above). According to a sign posted in the shrine, the shrine contains the miraculously preserved remains of a thirty-nine day old male child, named Sirirot Phibunsin, nicknamed Ae. The remains, coated in gold paper, are placed in a glass case surrounded by toy offerings and covered in paper currency.

The story of 'Nong Ae', or Baby Ae, was told in a popular ghost magazine, Khon Hen Phi, or 'People Seeing Ghosts' (Luang Phi 48 2012). According to this account, the baby was the child of a police officer. When the baby died his body was brought to Wat Mahabut. When the father was transferred away from Prakhanong (the district in which Wat Mahabut is located) the family thought they should have a funeral/cremation for the child without leaving commitments unmet. On the day of the funeral, when the coffin was opened for one last look at the baby the father was startled to see the body had not decayed. He kept the body and was going to consult with relatives. Even more amazingly, the baby came to the father in a dream and told him to keep this un-decayed body at the temple and to not cremate it, so that he can bestow luck and fortune [chok lap] for worshippers. As a consequence, the father agreed to the child's wishes and had the remains placed in a glass case next to the shrine Luang Pho Yim, a well-known Buddha image. ${ }^{15}$ After visiting the Luang Pho Yim shrine, worshippers typically visit the kumanthong shrine where they ask for luck and fortune and have their wishes fulfilled. The story continues claiming that propitiators think Baby Ae should be bestowed to Nang Nak to be a foster child. According to the story, people said that they felt that this child is cared for by Nang Nak as a foster child and it is appropriate to call him the child of Nak Prakhanong (Nak of Prakhanong district). Thus, the fatherly figure of Luang Pho Yim, along with the

\footnotetext{
${ }^{14}$ The preservation of the body and its transfer to a larger vessel was reported to be performed by doctors from Sirirat Hospital, the central government hospital.

${ }^{15}$ For a more detailed account of Baby Ae's background, see McDaniel (2011b: 256)
} 
motherly figure of Nang Nak is completed with the addition of Baby Ae, and a kind of spiritual nuclear family is envisioned.

A growing ambivalence surrounding the practice of propitiating infant remains was evident when, in July 2012, shortly after the kumanthong trafficking story broke. While visiting Mahabut, I asked several vendors at the temple for the location of the 'kumanthong' shrine; they each looked away awkwardly and said that at this temple there were no kumanthong shrines, but only one for a 'child spirit' [winyan dek], and then vaguely gestured in its direction. I surmise that one of the reasons for this awkwardness was the recent news story in which the term kumanthong was used repeatedly in the context of nefarious activities such that the term became, perhaps temporarily, stigmatised in its association with actual corpses, 'black magic' and individual manipulation of child spirits.

While foetal/infant consecrated corpses, such as those found at Wat Pradu and Wat Mahabut, as well as the illegally procured ones, are understood to have supernatural power, the spirit of a foetus/infant/child may be housed in any shrine devoted to it, as is true of all spirits. Typically, a statue is placed in the shrine as a housing for the spirit. These shrines may be individually owned, as part of a household shrine for example, or placed in communal areas and supported by communities. Some shrines are specifically for kumanthong while in others the kumanthong serve as assistants [samunborihan $],{ }^{16}$ to share in the protective duties of the primary spirits.

One of the central roles of kumanthong is to provide protection for propitiators and members of the community if the shrine is communal. The power of particular shrines and their spirits, and individual experiences with these spirits, is the subject of the popular genre of ghost magazines. An example of the ways in which kumanthong, as well as other spirits, can assist those under his/her protection can be found in the story of the Saminphrai, or Tiger Spirit, shrine on Raminthra Road, Bangkok, covered in an issue of Khon Hen Phi (Sor Manisuwan 2012). In this story, the kumanthong is housed in a figurine and serves as helpful assistant to the primary spirit of the community shrine.

According to the story, the location of the shrine is a natural place for kumanthong, "Here there are kumanthong so that [people] think that this place was a dense jungle, so that when children died their bodies were buried here, and put in the care of the spirit of Mother Thorani [phra mae thorani, or Earth Goddess]. The bodies were not dug up for cremation. Infants who died were buried with Mother Thorani. The spirits are probably circling around waiting for rebirth [the timing of which] is uncertain" (Sor Manisuwan 2012: 6). The story continues that an old man in the community dreamed that the Tiger Spirit [pu cao samin phrai] told him to invite kumanthong to be in the shrine. The shrine was thus believed to house many powerful [mi ithariit]

\footnotetext{
${ }^{16}$ 'Minion' may be the best translation but without the negative association.
} 
kumanthong to share protective duties. The article continues that because of that dream you will now see child figurines or kumanthong statues set up at the shrine, with three main ones (black, gold and red kumanthong). These three child spirits [winyan dek] have magical power [saksit] and supernatural power [aphinihan] to protect and assist people by giving them luck/good fortune. The locals make sacrifices to them. The article then proceeds to tell a first-hand account of the story of a taxi driver who was driving at around nine in the evening and saw three boys around eight or nine years old, asking for a ride to the shrine. When the driver warned them about the dangers of being out alone, they said they appreciated his concern, but that they feared no one. When they reached the shrine, they had no money, and the taxi driver said that was okay, but warned them to not venture out alone so late at night in the future. They said they appreciated his good heartedness and bestowed him with good luck. The three boys walked toward the shrine and quickly vanished. The taxi driver suspected he had been visited by child spirits, but had never had such an experience before. Several days later they came to him in a dream and gave him two lottery numbers that eventually won one thousand Baht. In another example related in the same story in Khon Hen Phi, a woman was abducted by a taxi driver to the lane, and three children miraculously appeared and fought off the attacker in a very un-childlike way, according to the woman. Then a man in white appeared who escorted her to the mouth of the lane to call a taxi for the woman. When she turned to thank him, he was gone. Only later did she realise that these were the kumanthong and $\mathrm{Pu}$ Cao Saminphrai (Tiger Spirit) of the shrine who had helped her.

This section has outlined two types of kumanthong shrine - one using a consecrated corpse of foetus/infant and the other using a figurine or statue to house child spirits who are perceived to be roaming the world awaiting rebirth. The kumanthong shrines provide a field of merit for propitiators by allowing them to care for a child, make merit for that child, and to also provide an opportunity for that child to make merit for him/herself by aiding the propitiator.

The need for merit making was a central rationale for the existence of the kumanthong, and thus a brief explanation of merit is in order. Making merit [tham bun] refers to acts of generosity and kindness that lead to the improvement of one's karmic status. While supporting Buddhism in the form of temple donations or providing for monks on their daily alms rounds are seen as particularly meritorious, all types of assistance to others may be understood as meritaccruing. However, as Monica Lindberg Falk (2007) explains, giving alms to monks $[$ dana $]$ is based on non-reciprocity and respect such that the monk does not reciprocate for the alms he receives for to do so would be to invalidate the act of giving alms and the merit accrued from the act. Everyday acts of generosity [caga], on the other hand, may indeed be reciprocated, as they are motivated primarily by pity (Falk 2007: 141-143). Both types of giving lead to the accrual of merit, or bun. The accumulation of merit is believed to alleviate suffering in 
either this life or the next and to aid in the cycle of rebirth, or reincarnation. Therefore, caring for the child leads to an accrual of merit on behalf of the 'parents', and the assistance the kumanthong provides his/her guardians leads to an accrual of merit preparing the child for their next birth. ${ }^{17}$

Wondering if people had qualms about propitiating child spirits that in a sense bound them to this world and possibly prevented the natural cycle of rebirth according to Buddhist principles, I questioned a temple monk who was watching over the shrine at Wat Pradu. The monk said these practices do not bind the child spirits to this life and that the kumanthong came of their own free will to inhabit the shrine. All propitiators of kumanthong in this research insisted that their relationship with kumanthong was voluntary. He explained that when it was time for the spirits to go, that is be reincarnated, they would go. The monk explained that since the twins were stillborn they never had the opportunity to make merit to fuel the wheels of karmic rebirth, and by residing for a time at the temple they can help the temple by attracting visitors and merit makers. These visitors, who came by the bus load, supported the temple with offerings and donations. The visitors came because the twins had a reputation as powerful helper spirits that could be propitiated to bring fortune to their propitiators.

Public kumanthong shrines are part of a panoply of public shrines to spirits and deities that exist in Thailand. However, there is something in the nature of the child that makes kumanthong particularly suitable for individual propitiation. While most spirits would not be invited into an individual's home, or made part of the family, this is precisely what occurs with child spirits. In this respect in the final part of this article, we now turn to explore relationships of individuals to kumanthong, either in the form of commodified kumanthong collections or personal relationships with kumanthong without focus on the kumanthong object.

\section{Collectors/Guardians}

For some devotees, kumanthong are primarily the physical object that houses the child spirit. As such, these items can be bought and sold and have a market value attached to them based on factors such as their age, magical expertise of specialists (monk or layperson) who invested the statue with supernatural power and the related perceived potency of accompanying child spirit, and aesthetics. Kumanthong collection is currently popular with urban middle class collectors with money to invest in pricey figurines and amulets. For these propitiators, it is the thing itself - the actual statue - that is the kumanthong, such that the spirit cannot be meaningfully disassociated with its material housing. In this

\footnotetext{
${ }^{17}$ See Falk (2007) for more discussion of merit and fields of merit.
} 
sense, the kumanthong are very much like amulets that house impersonal supernatural forces that can be used by its owner. The amulet does not typically house a personal spirit with a history - they are not personalised in this way. The preserved foetal/infant corpses bought and sold by individuals (illegally) are perhaps best seen as this kind of impersonal amulet-like supernatural power, which will contrast strikingly with the sometimes disembodied (that is, not housed in a statue/figurine, but free-floating) child-spirit companions.

One collector, twenty-one year old Kay, has collected approximately sixty kumanthong statues. The process in which the statue was made, including the status of the maker, is of central importance in determining its value. According to Kay, the keji acarn, or magical expert, is preferably a monk. When Kay described his collection he focused on the magical properties of the amulet versus the personality and person relationship of the spirit. He also stressed that the most valuable kumanthong were those that had been created by monks rather than laypeople. The magic that is required to make a kumanthong is thus positioned within established Buddhist institutions and distanced from the negative associations of practitioners of 'black magic' [mon dam]. As kumanthong practices become popular with members of the middle classes a shift has occurred to accommodate bourgeois sensibilities in which the negative associations of magic are downplayed, or repositioned as part of what determines the commodity's value.

For many devotees, on the other hand, kumanthong are seen as naturally occurring, voluntary interactions with child spirits. While a statue or figurine may be used to house the spirit, these objects have very little if any value in themselves. They may be made from inexpensive plastic figurines or even toys. The services of magical experts such as spirit mediums or Buddhist monks may be sought after for assistance in making contact and forming a relationship with the child spirit, but in some cases no intermediary is necessary to form a relationship.

In contrast to the elaborate magical rituals that comprise the kumanthong of legend, such as is found in Khun Chang Khuan Phaen, contemporary spirits often come to people in their dreams. For example, Ying, a woman in her late 60s, described a series of dreams she had when she first married her second husband and moved into his home. She claimed that in this dream a small boy, a toddler, came to her and begged for attention and care. She dreamt of playing with him, and bathing him, and other acts of nurturance. She described these dreams as extremely pleasant and said they lasted for a period of weeks. In the dreams, the child aged, and by the end of the several week period he was school aged. She said that she wanted to buy the child some toys, which would essentially form a guardianship relationship with him, but her husband was fearful and placed a protective design, or yantra, on the door of the house. After this time, the child no longer came to her in her dreams, and she felt sadness at his loss. 
Some devotees form lasting relationships with these kumanthong who come to them in dreams, and often formalised the relationship by obtaining small statues for the spirit to inhabit. Kaew dreamt of a boy who called to her and asked if he could stay. She said he was dressed like a kumanthong; he was wearing congkrabeng and had a top knot. She asked him in the dream if he would come and help her and he nodded. Some months later she felt his presence. While some kumanthong never were given a specific residing place, most devotees used the services of a ritual specialist, typically a spirit medium, to formally invest the statue with the spirit. Other spirits may be acquired directly from a ritual specialist, often a spirit medium, who may claim to house dozens of spirits ready for adoption. The fee paid to the ritual specialist varies, ranging from less than one hundred Baht to thousands of Baht. ${ }^{18}$

Child spirits are sought because they are understood to be more controllable than adult spirits. Some devotees called them pure [borisut] (even angelic for some practitioners) in comparison to other spirits. However, they are not without danger. At the very least, they can be mischievous and destructive. Kumanthong may anger and punish their guardian. Guardians describe kumanthong as potentially causing harm such as turning over household objects or even pushing somebody down the stairs. Some guardians claimed that their mischief could even cause someone's death in some extreme cases. These spirits may be returned to the temple or the spirit medium from which they were obtained. On the other hand, if the guardians do not attentively tend to the spirits they will leave on their own. The main goal of the propitiators is to keep their kumanthong happy so that they will continue with the relationship. There is thus a contractual aspect to this relationship. If one takes on the responsibility of a kumanthong one must take great care to fulfil assiduously one's end of the bargain. While there is a potential danger with the kumanthong, through patient and conscientious caretaking guardians can teach them to be obedient. Jim described this process as teaching the spirit to chua-fang or to listen to her obediently.

Guardians make physical offerings to their kumanthong, offering things such as red soda, snacks, and toys; however, most devotees describe the importance of a mental connection to their spirit. The spirit must be thought of often and invited to partake in family meals. According to Jim, the spirit must be told if a visitor is to come and spend the night: "When a visitor comes, you have to say, 'a friend is coming over, okay? Please don't tease [klaeng] the visitor, okay?"”

The spirits may possess their guardians either to protect their guardian or to get something that they (the spirits) desire. Jim described an event in which a kumanthong physically possessed her when denied a chance to celebrate a birthday with her friends. The friend, who also has a kumanthong, invited her kumanthong to go with them. Jim told her own kumanthong that it was not

\footnotetext{
${ }^{18}$ US $\$ 1$ equates to approximately 30 Thai Baht.
} 
necessary for him to go with them, and that he should stay and watch over the house, which was his primary duty. When they were cutting the birthday cake she described having the odd feeling of desiring it even though it was chocolate and she has never liked chocolate cake. This feeling of craving the cake overcame her and she ate it. While she was eating the cake, she broke a glass and stepped in the glass carelessly. She continued to eat oblivious to the fact that she was bleeding. She became aware of herself once again the next morning, after having a disturbing dream. She dreamt she went to a party and a naked child was hanging off her clothing. The child was a "mixed sex" and he/she urinated on her and was shouting "are you scared yet, are you scared yet? It's me!" She later dreamt this same dream. She hypothesises that the child was her friend's kumanthong reacting to wanting cake but not being able to have some unless he actually possessed Jim.

Generally, kumanthong are thought to provide benefits to their guardians and their household. While some of the benefits are rather mundane, everything from lottery numbers given to their guardians in dreams or whispered in their ear, to parking places; other benefits are a more encompassing caretaking relationship that includes protection and friendship. Maew, a college student in her early twenties, said when she was a child she had asthma and her father described the kumanthong watching over her as she slept. She said nights when she had trouble breathing, the kumanthong would sit with her and she would feel better when she woke up. This kumanthong took the role of a sibling, and she described him playing with toys as a child, and now being a young adult like herself, twenty or thirty years old. Likewise, Ying, said that her kuman-kaew (female kumanthong) is a companion to her who is always present. She said that whenever she has problems, she talks to her. She described her kuman-kaew as her 'friend'.

In some ways kumanthong play the role of traditional household or matrilineal spirits. ${ }^{19}$ For example, Ying explained that a relative got married and brought the husband to stay with her without asking permission from the kumanthong. The next morning, a child's footprints were found near the household alter as if a child had been angrily stomping his feet. (Ying surmised the spirit was the male kumanthong who expressed such anger).

For many of kumanthong guardians, there are no clear distinctions between sentimental and material attachments to their spirit. Here we can return to the concept of bunkhun, and see that the reciprocal ties that exist between guardians and their spirits are multi-faceted. Caretaking between parents and their children involve oscillations between providing emotional and material support in both directions. In this way, the relationship with the kumanthong has little difference from the types of expectations that normatively exist between parents and their children.

\footnotetext{
${ }^{19}$ For more on matrilineal spirits, see Walker (2006).
} 


\section{Conclusion}

The kumanthong point to a type of meta-discourse on the nature of childhood itself - they serve as a place of reflection on the various ways in which the child may be configured and the purposes for which they may serve. They are a field in which anxieties and complex contradictory attitudes towards the child are made manifest and experienced. Kumanthong are innocent, but also powerful and dangerous. They are commodities but also companions. They become part of the family but can be returned if proved unsatisfactory. They can communicate with this world, but are not of this world. They have a life force animating them, but they are dead.

The association of children with death is one key area of ambivalence, found in the trend to refer to kumanthong as thep, or heavenly beings, rather than phi, or ghosts. This ambivalence is also found in the discomfort over the use of foetal corpses. While shrines housing baby corpses are reputed to have great supernatural power that is useful to the community and individual supplicants, an ambivalence is emerging regarding the propriety of using child corpses, particularly those that are to be used for individual benefit rather than those housed in a Buddhist temple and/or available as a public resource. Alongside these traditional beliefs in the spiritual potency of foetal bodies, kumanthong are also understood to be more purely spiritual entities who may come to their guardians in dreams.

The idea of child ghosts as a resource to be used is also held with ambivalence. The kumanthong are understood to come of their own free will and most propitiators insist that the kumanthong are free to leave when they wish. Magical spells to control the kumanthong are considered cruel, and in place of controlling magic are now contractual relationships in which the duties and responsibilities of parenthood and childhood are made explicit.

The kumanthong, on one level, is a historical and literary reference to the product of iconic masculinity, in which the sexually powerful male can subvert the female birth process and exert male control over offspring, and produce a supernaturally powerful extension of male virility. In this form, kumanthong seems comparable to amulets such as shiva lingums, which are propitiated and valued by both men and women, but are iconically a form of masculine generative power. ${ }^{20}$ The contemporary interpretation of kumanthong as vulnerable children in need of caretaking may perhaps be seen as a recuperation of female generative power, symbolically kidnapped in the Khun Phaen story.

Kumanthong also reflect of kind of modern family institution in which parental-child relations are figured as an exchange of duties and responsibilities. Kumanthong represent a kind of role reversal, with the parent seeking to manage the superior supernatural power of the child and to marshal it for achieving very real world ends. The current popularity of child ghosts reflects a

\footnotetext{
${ }^{20}$ Shiva lingum are phallic symbols based on Indic iconography.
} 
fascination and awe of child spiritual power, and also a recognition of the benefits that can be had by using children for their access to the supernatural. Within the kumanthong is a reconciliation of both affective and material needs, and these needs are explicitly linked to a model of contractual parenthood in which the parental-child relationship exists so long as it is mutually beneficial and is not necessarily a relationship for life. The kumanthong are ideally voluntary participants, and as such have autonomy and rights, both upholding contemporary concern with child rights yet challenging the passivity and helplessness that the transnational discourses on child rights implicitly promotes.

\section{References}

Ariès, Philippe. 1962. Centuries of Childhood: A Social History of Family Life. New York: Vintage Books.

Baker, Chris, and Pasuk Phongpaichit (eds.) 2010a. The Tale of Khun Chang Khun Phaen. Chiang Mai: Silkworm Books.

Baker, Chris, and Pasuk Phongpaichit. (eds.) 2010b. The Tale of Khun Chang Khun Phaen (companion volume). Chiang Mai: Silkworm Books.

Baker, Simon. 2007. 'Child Labor' and Child Prostitution in Thailand: Changing Realities. Bangkok: White Lotus Press.

Boyden, Jo. 1997. Childhood and the policy makers: a comparative perspective on the globalization of childhood. In A. James and A. Prout (eds.), Constructing and Reconstructing Childhood: Contemporary Issues in the Sociological Study of Childhood, pp. 190-229. London: Falmer Press.

Chakraphan Karnsompop and Chakraphong Karnsompop. n.d. Kumanthong. (No publisher named).

Falk, Monica Lindberg. 2007. Making Fields of Merit: Buddhist Female Ascetics and Gendered Orders in Thailand. Seattle: University of Washington Press.

Falk, Monica Lindberg. 2013. Buddhism as a vehicle for girls' safety and education in Thailand. In Vanessa R. Sasson (ed.), Little Buddhas: Children and Childhood in Buddhist Texts and Traditions, pp. 266-289. Oxford: Oxford University Press.

Gross, Rita. 1996. Child and family in Buddhism. In Howard Coward and Philip Cook (eds.), Religious Dimensions of Child and Family Life: Reflections on the UN Convention on the Rights of the Child, pp. 79-98. Waterloo: Wilfrid Laurier University Press.

Jakobsen, Janet and Pellegrini, Ann. 2003. Love the Sin: Sexual Regulation and the Limits of Religious Tolerance. Boston: Beacon Press.

Hardacre, Helen. 1997. Marketing the Menacing Fetus in Japan. Berkeley: University of California Press.

Heywood, Colin. 2001. A History of Childhood: Children and Childhood in the West from Medieval to Modern Times. London: Polity.

James, Allison and Prout, Alan (eds.) 2007. Constructing and Reconstructing Childhood: Contemporary Issues in the Sociological Study of Children (2nd Edition). London: Falmer Press.

Lancy, David. 2008. The Anthropology of Childhood: Cherubs, Chattel, Changelings. Cambridge: Cambridge University Press.

Lesko, Nancy and Talburt, Susan (eds.) 2011. Keywords in Youth Studies: Tracing Affects, Movements, Knowledges. New York: Routledge 
Luang Phi 48. 2012. Kumanthong (Sirirot), People Seeing Ghosts [khon hen phi]. Year 6, issue 79, June 16-30, 2012: 1, 6-8.

Marshall, Elizabeth. 2011. Innocence. In Nancy Lesko and Susan Talburt (eds.), Keywords in Youth Studies: Tracing Affects, Movements, Knowledges, pp. 295-299. New York: Routledge.

McDaniel, Justin. 2011a. The Lovelorn Ghost and the Magical Monk: Practicing Buddhism in Modern Thailand. New York: Columbia University Press.

McDaniel, Justin. 2011b. The Agency between Images: the relationship among ghosts, corpses, monks, and deities at a Buddhist monastery in Thailand. Material Religion, $7(2), 242-267$.

McDaniel, Justin. 2013. Superheroes and slapstick: new media and the teaching of Buddhist children in Thailand. In V. R. Sasson (ed.), Little Buddhas: Children and Childhood in Buddhist Texts and Traditions, pp. 290-304. Oxford: Oxford University Press.

Moskowitz, Marc. 2001. The Haunting Fetus: Abortion, Sexuality, and the Spirit World in Taiwan. Honolulu: University of Hawaii Press.

Nakagawa, Yoshiharu. 2006. The child as compassionate Bodhisattva and as human sufferer/spiritual seeker: intertwined Buddhist images. In Karen Marie Yust, Aostre N. Johnson, Sandy Eisenberg Sasso and Eugene C. Roehlkepartain (eds.), Nurturing Child and Adolescent Spirituality: Perspectives for the World's Religious Traditions, pp. 33-42. Lanham: Rowman \& Littlefield Publishers, Inc.

Sasson, Vanessa R. 2013. Introduction: charting new territory: children and childhoods in Buddhist texts and traditions. In V. R. Sasson (ed.), Little Buddhas: Children and Childhoods in Buddhist Texts and Traditions, pp. 1-14. Oxford: Oxford University Press.

Shepler, Susan. 2005. The rites of the child: global discourses of youth and reintegrating child soldiers in Sierra Leone. Journal of Human Rights 4, 197-211.

Sor Manisuwan. 2012. Miraculous Kumanthong [aphiniharn kumanthong]. People Seeing Ghosts [khon hen phi]. Year 6, issue 81, July 16-31, 2012:1, 6-8.

Walker, Andrew. 2006. Matrilineal spirits, descent and territorial power in northern Thailand. Australian Journal of Anthropology 17(2), 196-215.

Waraporn Chamsanit. 2008. The Thai Government's Way of Thinking about Sexuality [withi chiwit rueang pheet wii-ihii khong rat thai]. Bangkok: The Women's Health Advocacy Foundation, Thai Health Promotion Foundation, and the Institute for Population and Social Research, Mahidol University.

Zhao, Guoping. 2011. The modern construction of childhood: what does it do to the paradox of modernity? Studies in Philosophy \& Education 30, 241-56.

Zelizer, Viviana A. 1994. Pricing the Priceless Child: The Changing Social Value of Children. Princeton, N.J.: Princeton University Press. 